\title{
Tick salivary gland extract-activated transmission of Borrelia afzelii spirochaetes
}

\author{
Jitka Pechová ${ }^{1}$, Gabriela Štěpánová ${ }^{1}$, Lubomír Kovár $^{2}$ and Jan Kopecký ${ }^{1}$ \\ ${ }^{1}$ Institute of Parasitology, Academy of Sciences of the Czech Republic, Branišovská 31, 37005 České Budějovice, Czech \\ Republic; \\ ${ }^{2}$ Institute of Microbiology, Academy of Sciences of the Czech Republic, Vídeňská 1083, 14220 Prague, Czech Republic
}

Key words: Ixodes ricinus, salivary gland extract, Borrelia afzelii, transmission

\begin{abstract}
Saliva-activated transmission of Borrelia afzelii Canica, Nato, du Merle, Mazie, Baranton et Postic, 1993 was demonstrated using salivary gland extract (SGE) from Ixodes ricinus (L., 1758) ticks and C3H mice. Injection of Borrelia spirochaetes together with SGE increased the level of bacteraemia and accelerated the appearance of bacteria in the urinary bladder, compared with the injection of spirochaetes alone. More I. ricinus nymphs became infected when feeding on mice inoculated with $B$. afzelii plus SGE. Analysis of cytokines produced by cells of draining lymph nodes from SGE-treated mice showed a suppression of proinflammatory cytokines IFN- $\gamma$, IL-6 and GM-CSF following a transient upregulation in comparison with the control mice infected without SGE.
\end{abstract}

The relationship between the tick-borne pathogen, Borrelia burgdorferi sensu lato, its diverse hosts and ixodid tick vectors is represented by a triangle of parasitic interactions (Nuttall 1999). The important component of this triangle is the interaction between the tick and its host which occurs in the skin at the tick feeding site. Attachment and feeding takes several days to complete, providing an opportunity for the host haemostatic and immune system to affect the tick. The feeding success depends on an array of pharmacologically active substances in tick saliva operating against the host's response. Increasing evidence strongly suggests that a key factor in successful transmission of tickborne pathogens is the ability of these pathogens to exploit the pharmacological properties of tick saliva (Nuttall 1999).

In addition to antihaemostatic and vasoactive effects, tick saliva possesses broad immunomodulatory activities affecting both innate (nonspecific) and adaptive (specific) immunity of the host. Tick saliva or salivary gland extracts (SGE) inhibit activation of the alternative pathway of complement (Ribeiro 1987), inactivate anaphylatoxins (Ribeiro and Spielman 1986), and prevent phagocytosis and the production of superoxide by neutrophils (Ribeiro et al. 1990). The inhibitory effect of tick saliva on the production of nitric oxide by macrophages has also been demonstrated (Urioste et al. 1994). More recently, inhibition of NK cell activity (Kubeš et al. 1994), inhibition of the antiviral action of interferon (Hajnická et al. 2000), histamine-binding capacity (Paesen et al. 1999) and immunoglobulinbinding capacity (Wang and Nuttall 1995) of tick saliva have been reported.
Tick feeding impairs the ability of lymphocytes to proliferate after stimulation with $\mathrm{T}$ mitogens (Wikel 1982). This effect of tick saliva can be explained by the activity of an IL-2 binding protein, which has been recently identified in the saliva of Ixodes scapularis (Gillespie et al. 2001). Polarisation of the host immune response to a T-helper 2-type cytokine profile has been repeatedly demonstrated after feeding of various tick species (Ferreira and Silva 1999, Schoeler et al. 1999). Upregulation of Th2 cytokines (IL-4, IL-10, TGF- $\beta$ ) with strong anti-inflammatory activity probably makes the host susceptible to both tick and tick-transmitted pathogens.

Promotion of vector-borne pathogen transmission, via the action of vector saliva on the host, has been termed saliva-activated transmission (SAT) (Nuttall and Jones 1991). SAT was demonstrated by the enhancement of infectivity when Thogoto arbovirus plus SGE was syringe-inoculated into a host, compared with the level of infectivity when the virus alone was injected (Jones et al. 1989). Data presented herein demonstrate for the first time SAT of a non-viral pathogen, the spirochaete Borrelia afzelii Canica, Nato, du Merle, Mazie, Baranton et Postic, 1993.

\section{MATERIALS AND METHODS}

Mice. Specific-pathogen-free female $\mathrm{C} 3 \mathrm{H} / \mathrm{HeN}$ mice, 6 to 10 weeks old, purchased from Charles River, Sulzfeld, Germany, were used in the study.

Bacteria. The CB-43 strain of Borrelia afzelii isolated from an Ixodes ricinus (L., 1758) female (Štěpánová-Tresová et al. 1999) was grown in Barbour-Stoenner-Kelly-H (BSK-H) medium (Sigma) supplemented with $6 \%$ rabbit serum at $34^{\circ} \mathrm{C}$. 
The number of spirochaetes was calculated by dark-field microscopy according to Magnusson et al. (1948). The fourth passage was used in the experiments.

Salivary gland extract. Adult I. ricinus ticks from the colony of the Institute of Parasitology, Academy of Sciences of the Czech Republic in České Budějovice were screened for B. burgdorferi sensu lato by PCR with negative results. Ticks were fed in groups of 20 mating pairs within retaining cells attached to the backs of guinea pigs. After 5 days engorged female ticks were removed, and the salivary glands were dissected from the live ticks and pooled. After washing in phosphate-buffered saline (PBS), the salivary glands were homogenised in $1 \mathrm{ml}$ of PBS by sonication and clarified by centrifugation at $10,000 \mathrm{~g}$ for $10 \mathrm{~min}$. The protein concentration of clarified SGE was determined using a protein estimation kit (BioRad, Richmond, CA, USA). Aliquots of the $\mathrm{SGE}$ preparation were stored at $-70^{\circ} \mathrm{C}$.

Experimental infection of mice. A group of 15 mice was subcutaneously injected in the interscapular area with $10^{6}$ spirochaetes mixed with $40 \mu \mathrm{g}$ of SGE protein in $0.1 \mathrm{ml}$ of PBS per mouse. The control group of 15 mice was inoculated only with $10^{6}$ spirochaetes in the same volume of PBS. On days 1, 2, 3, 5, 7 and 9 post infection (p.i.) samples of blood were taken from the orbital sinus of three mice for each time point, under ether narcosis. Ninety $\mu 1$ of heparinised blood was inoculated into $5 \mathrm{ml}$ of BSK-H medium supplemented with $65 \mu 1$ of antibiotic mixture for borrelia (Sigma) and incubated at $34^{\circ} \mathrm{C}$. On days $7,9,12$ and 15 p.i. three mice for each time point were killed, their urinary bladders were aseptically dissected and placed into $5 \mathrm{ml}$ of BSK-H medium with antibiotics. Cultures were examined for the presence of spirochaetes after 6 days of incubation. In positive samples, the number of spirochaetes was determined after indirect immunofluorescence staining.

SAT assay. On the day of experimental infection of the mice (see above), 10 I. ricinus nymphs from the colony of the Institute of Parasitology, České Budějovice were placed into a retaining cell attached to the back of 3 mice inoculated only with spirochaetes and 3 mice inoculated with spirochaetes + SGE. A sample of nymphs from the population used in the assay were tested for the presence of $B$. burgdorferi sensu lato by PCR with negative results. Nymphs were allowed to feed until fully engorged (3-4 days), collected and maintained at $22^{\circ} \mathrm{C}$ and a relative humidity $95 \%$ for 14 days. Then DNA was isolated from engorged nymphs using TRI-reagent BD (Sigma) according to the manufacturer's instructions.

Indirect immunofluorescence. Two $\mathrm{ml}$ of spirochaetepositive culture were centrifuged at $10000 \mathrm{~g}$ for $15 \mathrm{~min}$ and the pellet was washed in PBS three times. The final pellet was resuspended in $500 \mu \mathrm{l}$ of PBS and $20 \mu \mathrm{l}$ sample was dropped on a slide well. After fixation in cold acetone for $10 \mathrm{~min}$, bacterial cells were incubated with borrelia-hyperimmune mouse serum diluted in PBS 1:50 for $30 \mathrm{~min}$ at $37^{\circ} \mathrm{C}$. Slides were washed in PBS and goat anti-mouse polyvalent immunoglobulin FITC conjugate (Sigma) was applied in the dilution $1: 100$. Slides were incubated for $30 \mathrm{~min}$ at $37^{\circ} \mathrm{C}$, washed and mounted in DABCO (Sigma) mounting medium. Spirochaetes in the whole sample were counted under a Jenalumar epifluorescence microscope (Germany) at $\times 400$ magnification.
Detection of Borrelia burgdorferi sensu lato DNA by PCR. The B. burgdorferi DNA present in tick samples was amplified by PCR (in Mastercycler ${ }^{\mathrm{R}}$ Eppendorf) using oligonucleotide primers (produced by Generi Biotech, Czech Republic) SL 1: 5'-AATAGGTCTAATAATAGCCTTAAT AGC-3' and SL 2: 5'-CTAGTGTTTTGCCATCTTCTTTGA AAA-3' (Chang et al. 1998) for the target sequence of the ospA gene of B. burgdorferi sensu lato. PCR was performed in a reaction volume of $50 \mu \mathrm{l}$ containing $15 \mu \mathrm{l}$ of the processed tick sample, $1 \times$ PCR buffer, $1.5 \mathrm{mM} \mathrm{MgCl} 2,0.2$ mM each triphosphate (dATP, dTTP, dCTP and dGTP), 0.5 $\mu \mathrm{M}$ oligonucleotide primers and 2.5 U Taq DNA polymerase (GIBCO BRL). Each of the samples (after initial DNA denaturation at $95^{\circ} \mathrm{C}$ for $5 \mathrm{~min}$ ) was amplified for 35 repeated cycles of denaturation at $94^{\circ} \mathrm{C}$ for $1 \mathrm{~min}$, annealing at $55^{\circ} \mathrm{C}$ for $1 \mathrm{~min}$, chain elongation at $72^{\circ} \mathrm{C}$ for $2 \mathrm{~min}$ and final polymerisation (at $72^{\circ} \mathrm{C}$ for $8 \mathrm{~min}$ and at $68^{\circ} \mathrm{C}$ for $15 \mathrm{~min}$ ). PCR amplification products were resolved on a $2 \%$ agarose electrophoresis gel and visualised under UV light with ethidium bromide. Size of the PCR product was $307 \mathrm{bp}$. We were able to detect $\geq 10$ borreliae per tick in blood-fed nymphal ticks by this method.

Ex vivo cell cultures. Axillary, branchial and cervical lymph nodes from infected, SGE-treated or untreated mice (see experimental infection of mice) were removed, mashed through a sterile grinder and washed twice in RPMI-1640 medium without serum. Lymph node cells $\left(2 \times 10^{5)}\right.$ in RPMI1640 supplemented with $10 \%$ foetal calf serum, $0.05 \mathrm{mM} \mathrm{2-}$ mercaptoethanol and antibiotics (antibiotic-antimycotic, Sigma) were stimulated with Concanavalin A (ConA) at 5 $\mu \mathrm{g} / \mathrm{ml}$ or left unstimulated. Supernatants were harvested at 24 $\mathrm{h}$ after stimulation and stored at $-65^{\circ} \mathrm{C}$ prior to cytokine determination. Lymph node cells from three mice were used for each time point after infection.

Cytokine detection. Antibody-sandwich enzyme-linked immunosorbent assay was performed using matched pairs of monoclonal antibodies (MAbs) as specified by the manufacturer. Capture and detection MAb pairs used in this study were as follows: IFN- $\gamma$, clones MCA 1394 and MCA 1548B (Serotec, Kidlington, UK); IL-6, MAB 406 and BAF 406; GM-CSF, MAB 415 and BAF 415 (both R\&D Systems, Minneapolis, MN, USA); IL-10, 18141D and 18152D (PharMingen, San Diego, CA, USA). Wells of high binding flat bottom EIA/RIA plates (Costar, Cambridge, MA, USA) were coated with $50 \mu \mathrm{m}$ of MAb overnight at $4^{\circ} \mathrm{C}$. MAbs were diluted in a coating solution (0.1 M NaHCO, $\mathrm{pH} 8.2)$ to a concentration of 2-6 $\mu \mathrm{g} / \mathrm{ml}$. After blocking with $10 \%$ newborn calf serum (NCS) in PBS for $2 \mathrm{~h}$ at room temperature, samples $(50 \mu \mathrm{l} /$ well) were added in triplicate and incubated overnight at $4^{\circ} \mathrm{C}$. Plates were then incubated with biotinylated MAbs $(100 \mu \mathrm{l} /$ well) at a concentration $0.2-2 \mu \mathrm{g} / \mathrm{ml}$ for $45 \mathrm{~min}$ at room temperature. Subsequently $100 \mu \mathrm{l}$ of streptavidin peroxidase (Sigma) diluted 1000-fold were added and incubated for $30 \mathrm{~min}$ at room temperature. The substrate for the enzymatic colour reaction was 2.2'-azino-bis-(3-ethylbenzthiazoline-6-sulphonic acid) (ABTS, Sigma, $100 \mu 1 /$ well). After $10 \mathrm{~min}$ of incubation, the reaction was stopped by adding $50 \mu 1$ of $1 \%$ sodium dodecyl sulphate. Optical densities were measured at $403 \mathrm{~nm}$ with an ELISA spectrophotometer (Multiskan MCC 340, Labsystems Oy, Helsinki, Finland). 
After each incubation the plates were washed at least three times with $0.05 \%$ Tween 20 in PBS. Results show the mean of triplicate wells from each experiment. Serial dilutions of recombinant cytokines (R\&D Systems, Minneapolis, MN, USA) were used to generate the cytokine standard curves. As the supernatants for the cytokine detection were not harvested on the same day, cytokine levels are expressed as \% control, i.e., ng per $\mathrm{ml}$ of the cytokine in the SGE-treated group divided by the level of the cytokine in the control SGEuntreated group and multiplied by 100 .

Statistical analysis. The significance of any differences obtained between experimental groups was evaluated by the Student's $t$-test.

\section{RESULTS}

The effect of I. ricinus SGE on the infection of $\mathrm{C} 3 \mathrm{H}$ mice with B. afzelii spirochaetes was tested. Subcutaneous injection of spirochaetes mixed with SGE was compared with injection of spirochaetes alone. Bacteraemia was recorded in both groups from day 1 p.i. and continued until day 5 (Table 1). One blood sample taken from SGE-treated mice on day 7 p.i. was positive. A marked difference between the groups was observed in the numbers of spirochaetes in blood cultures from day 1 p.i. Eight-fold more spirochaetes were counted in the SGE-treated group compared with the SGEuntreated control (Table 2). In later intervals $(2,3,5,7$ and 9 days p.i.) the difference between both experimental groups was not significant (data not shown).

Spirochaetes appeared earlier in the urinary bladder of SGE-treated mice (Table 3). On day 15 post infection, when all the mice were positive, four-times more spirochaetes were found in cultures from urinary bladders of SGE-treated mice as compared with the untreated group (Table 4).

When pathogen-free $I$. ricinus nymphs were placed on both Borrelia-infected groups of mice, 57\% (16 of 28 nymphs) became infected in the SGE-treated group, while no infected nymphs (of 30 tested) were recorded in the control (Table 5).

Production of cytokines by ex vivo cell cultures from lymph nodes draining the inoculation site was studied using unstimulated and ConA-stimulated cells. IFN- $\gamma$, a representative of Th1 cytokines, was unchanged on day 2 p.i. in the SGE-treated group $(0.05 \mathrm{ng} / \mathrm{ml})$, while its levels significantly $(\mathrm{P}<0.05)$ declined by $17 \%$ (i.e., $0.32 \mathrm{ng} / \mathrm{ml}$ ) of the control level on day 5 and by $77 \%$ $(5.04 \mathrm{ng} / \mathrm{ml})$ on day 7 p.i. (Fig. 1). The antiinflammatory Th2 cytokine IL-10 was not changed in unstimulated lymph node cell cultures from SGE-treated compared with control mice on day 2 p.i. $(0.155 \mathrm{ng} / \mathrm{ml}$, Fig. 1). At later intervals nonsignificant suppression was observed in the SGE-treated group (control values 2.31 $\mathrm{ng} / \mathrm{ml}$ and $0.26 \mathrm{ng} / \mathrm{ml}$ on days 5 and 7 , respectively). A different pattern of IFN- $\gamma$ production was observed in ConA-stimulated cultures (Fig. 2). After a significant increase over the control (SGE-untreated) value on day
Table 1. Effect of Ixodes ricinus SGE on the incidence of Borrelia afzelii in the blood of $\mathrm{C} 3 \mathrm{H} / \mathrm{HeN}$ mice.

\begin{tabular}{|l|c|c|c|c|c|c|}
\hline & \multicolumn{7}{|c|}{ Days post infection } \\
& 1 & 2 & 3 & 5 & 7 & 9 \\
\hline B. afzelii & $2 / 3^{*}$ & $3 / 3$ & $3 / 3$ & $2 / 3$ & $0 / 3$ & $0 / 3$ \\
B. afzelii + SGE & $3 / 3$ & $3 / 3$ & $2 / 3$ & $2 / 3$ & $1 / 3$ & $0 / 3$ \\
\hline
\end{tabular}

*Number of positive cultures / number of cultures.

Table 2. Effect of Ixodes ricinus SGE on number of spirochaetes in the blood of $\mathrm{C} 3 \mathrm{H} / \mathrm{HeN}$ mice on day 1 post infection.

\begin{tabular}{|l|c|}
\hline & Average of 3 cultures $\pm \mathrm{SD}^{*}$ \\
\hline B. afzelii & $3.5 \pm 0.7$ \\
B. afzelii + SGE & $26.7 \pm 11.6^{* *}$ \\
\hline
\end{tabular}

${ }^{*}$ Blood was taken from three mice and cultured in BSK-H medium for 6 days; spirochaetes were counted in $20 \mu 1$ of blood culture. ${ }^{* *}$ The difference vs. SGE-untreated control significant at $\mathrm{P}<0.05$.

Table 3. Effect of Ixodes ricinus SGE on the incidence of Borrelia afzelii in urinary bladders of $\mathrm{C} 3 \mathrm{H} / \mathrm{HeN}$ mice.

\begin{tabular}{|l|c|c|c|c|}
\hline & \multicolumn{4}{|c|}{ Days post infection } \\
& 7 & 9 & 12 & 15 \\
\hline B. afzelii & $0 / 3^{*}$ & $0 / 3$ & $0 / 3$ & $3 / 3$ \\
B. afzelii + SGE & $0 / 3$ & $1 / 3$ & $2 / 3$ & $3 / 3$ \\
\hline
\end{tabular}

${ }^{*}$ Number of positive cultures / number of cultures.

Table 4. Effect of Ixodes ricinus SGE on number of spirochaetes in urinary bladders of $\mathrm{C} 3 \mathrm{H} / \mathrm{HeN}$ mice.

\begin{tabular}{|l|c|}
\hline & Average of 3 cultures \pm SD $^{*}$ \\
\hline B. afzelii & $3.3 \pm 1.2$ \\
B. afzelii + SGE & $13.3 \pm 4.7^{* *}$ \\
\hline
\end{tabular}

*Urinary bladders were dissected on day 15 p.i. and placed into BSK-H medium; spirochaetes were counted in $20 \mu \mathrm{l}$ of culture medium after 6 days of incubation. ${ }^{* *}$ The difference vs. SGE-untreated control significant at $\mathrm{P}<0.05$.

Table 5. Effect of Ixodes ricinus SGE on the transmission of Borrelia afzelii from the host to feeding Ixodes ricinus nymphs.

\begin{tabular}{|l|c|}
\hline \multicolumn{1}{|c|}{$\begin{array}{c}\text { Infection of the host } \\
\text { (C3H/HeN mice) }\end{array}$} & $\begin{array}{c}\text { No. infected nymphs/ } \\
\text { No. tested }\end{array}$ \\
\hline B. afzelii & $0 / 30(0 \%)$ \\
B. afzelii + SGE & $16 / 28(57 \%)$ \\
\hline
\end{tabular}

2 p.i. (1.44 ng/ml; P < 0.05) a nonsignificant suppression was recorded in SGE-treated group on day 5 p.i., followed by recovery to the control level.

The proinflammatory cytokines IL-6 and GM-CSF were not detected in ConA-unstimulated lymph node cell cultures (data not shown). ConA-stimulated lymph 


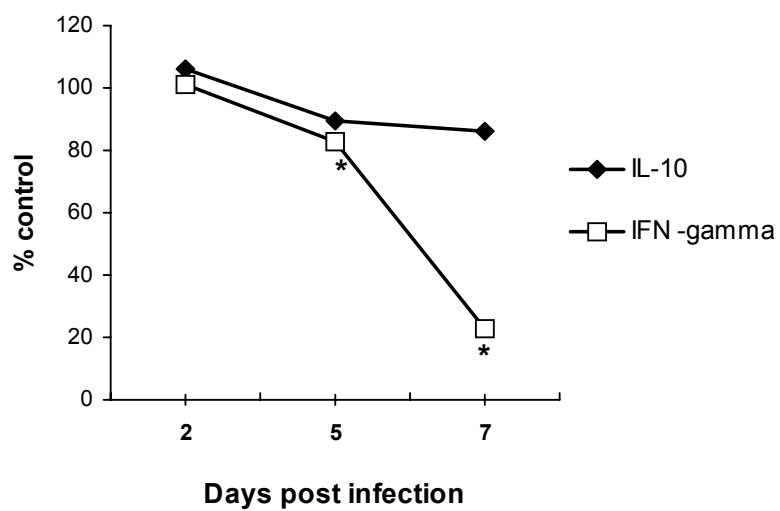

Fig. 1. Th1 (IFN- $\gamma$ ) and Th2 (IL-10)-associated cytokine production by lymph node cells from mice infected with Borrelia afzelii plus Ixodes ricinus SGE. Cytokine levels are expressed as \% control, i.e., $\mathrm{ng} / \mathrm{ml}$ of the cytokine in the SGEtreated group divided by the level of the cytokine in the control, SGE-untreated group, and multiplied by 100 . *Statistically significant $(\mathrm{P}<0.05)$ differences between SGEtreated and control groups.

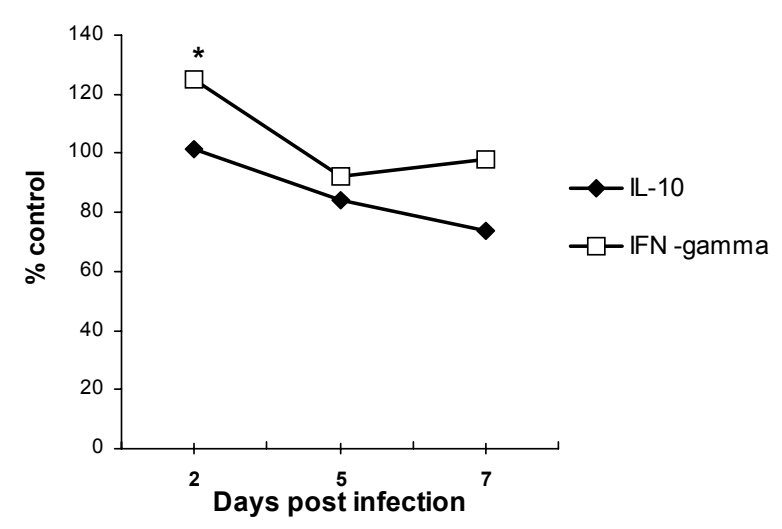

Fig. 2. Th1 (IFN- $\gamma$ ) and Th2 (IL-10)-associated cytokine production by lymph node cells from mice infected with Borrelia afzelii plus SGE and stimulated in vitro with ConA. Cytokine levels are expressed as \% control, i.e., $\mathrm{ng} / \mathrm{ml}$ of the cytokine in the SGE-treated group divided by the level of the cytokine in the control, SGE-untreated group, and multiplied by $100 .{ }^{*}$ Statistically significant $(\mathrm{P}<0.05)$ difference between SGE-treated and control groups.

node cells from spirochaetes+SGE-infected mice showed a marked $200 \%$ upregulation of IL-6 on day 2 p.i. $(0.705 \mathrm{ng} / \mathrm{ml} ; \mathrm{P}<0.01$ compared to $\mathrm{SGE}$-untreated mice), no difference from control value on day 5 and a slight decline on day 7 p.i. (Fig. 3).

GM-CSF was significantly (by 50\%) upregulated on day 2 p.i. $(1.518 \mathrm{ng} / \mathrm{ml}$; $\mathrm{P}<0.05$ compared to SGEuntreated mice), followed by nonsignificant suppression on day 5 and recovery to the control level on day 7 p.i.

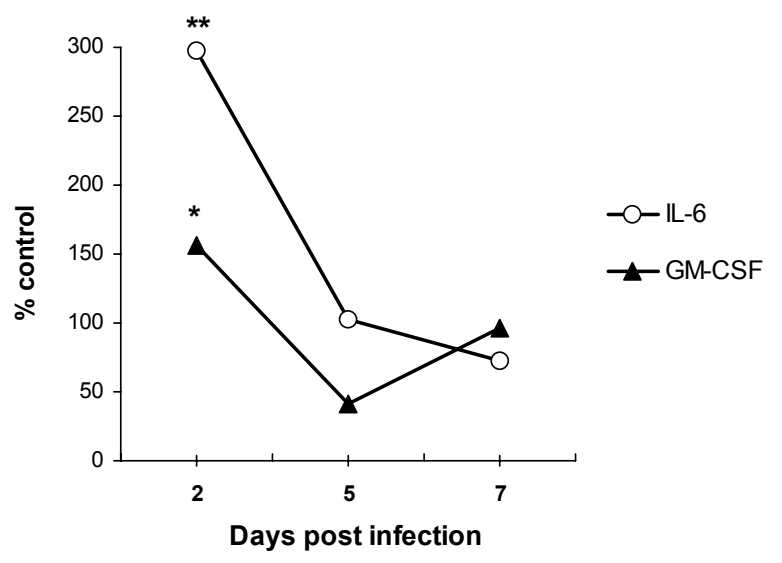

Fig. 3. Proinflammatory cytokine (IL-6, GM-CSF)-associated production by lymph node cells from mice infected with Borrelia afzelii plus SGE and stimulated in vitro with ConA. Cytokine levels are expressed as \% control, i.e., $\mathrm{ng} / \mathrm{ml}$ of the cytokine in the SGE-treated group divided by the level of the cytokine in the control, SGE-untreated group, and multiplied by $100 .{ }^{*}$ Statistically significant $(\mathrm{P}<0.05)$ difference between SGE-treated and control groups. ${ }^{* *}$ Significant difference at $\mathrm{P}<$ 0.01 .

\section{DISCUSSION}

Saliva-activated transmission of tick-borne pathogens has so far been demonstrated for arboviruses like Thogoto and TBE viruses (Nuttall 1999). For non-viral pathogens the evidence is only circumstantial, based on the fact that the transmission of Borrelia burgdorferi by tick bite is much more efficient than transmission of the pathogen by a syringe injection (Gern et al. 1993), and that efficient transmission of Borrelia spirochaetes can occur between cofeeding ticks without a systemic infection of the host (Ogden et al. 1997). To our knowledge we present in this paper the first work documenting promotion of the proliferation of an important non-viral pathogen, Borrelia afzelii, in the host by tick SGE. Although we could not demonstrate the effect of SGE on the onset of bacteraemia, accelerated proliferation of spirochaetes in the host was shown after cultivation of blood samples in BSK-H medium for 6 days. Even though we were not able to count the spirochaetes in the blood samples directly, we assume that numbers of spirochaetes after 6 days cultivation are proportional to the numbers of bacteria in the original samples when the proliferation rate is identical for all spirochaetes. It is unlikely that SGE, diluted in the host body and again after inoculation of blood samples into BSK-H medium, would still act as a growth factor for borreliae. But a direct support of spirochaete growth in the dermal site of infection can be taken into consideration. Another finding supporting the promoting effect of SGE on the course of infection was the earlier appearance of the spirochaetes in the urinary bladder, which could be associated with higher bacteraemia. 
An accelerating effect of tick SGE on the replication of vesicular stomatitis virus in murine L cells (Hajnická et al. 1998) was apparently connected with the paralysis of interferon antiviral action (Hajnická et al. 2000). Similarly, a mosquito feeding-induced enhancement of Cache Valley virus infection in mice was reported (Edwards et al. 1998). Salivary gland lysates of the sandfly Lutzomyia longipalpis markedly enhanced the course of infection with the protozoan Leishmania major in mice (Theodos et al. 1991). The immunosuppressive molecule in sandfly saliva, responsible for the exacerbation of Leishmania infection, was identified as maxadilan, a vasodilatory peptide (Gillespie et al. 2000). SGE from Phlebotomus papatasi, another sandfly species, dramatically exacerbated development of skin lesions in mice infected with L. major (Mbow et al. 1998). This exacerbation correlated with inhibition of the production of Th1 cytokines, but with enhancement of Th2 cytokine IL-4. The SGE effect resulted in the inhibition of the macrophage-killing molecule, nitric oxide.

Results similar to those reported here have been obtained with another tick-transmitted bacterial pathogen, Francisella tularensis (Kročová et al. unpublished). Injection with $I$. ricinus SGE promoted the proliferation of tularemic bacteria in the dermal sites of infection as well as in draining lymph nodes and spleens of infected mice. The higher rate of $F$. tularensis proliferation was accompanied by suppression of early attraction of CD4+ T lymphocytes into the dermal sites of infection and by reduced expression of MHC II antigens on antigen-presenting cells.

Injection of SGE mixed with Borrelia spirochaetes markedly increased the percentage of nymphs that became infected after feeding close to the inoculation site, in comparison to nymphs feeding on mice injected with spirochaetes alone. It is not clear from this finding if higher bacteraemia or better survival of spirochaetes in the skin is responsible for the increase of nymphal infection rate from $0 \%$ in the control group to $57 \%$ in the SGE-treated group.

Saliva-activated transmission likely has an immunological background. An anti-complement activity of tick saliva can be one of the mechanisms promoting $B$. burgdorferi transmission (Kurtenbach et al. 1998). If the interaction of the spirochaetes with professional phagocytes represents the first line of host defence (Georgilis et al. 1991), the anti-phagocyte effects of tick saliva could be another transmission-promoting mechanism. Suppression of both phagocytosis of Borrelia spirochaetes (Ribeiro et al. 1990) and borrelicidal mechanisms (superoxide and nitric oxide), resulting in reduced killing of spirochaetes (Kuthejlová et al. 2001), have been demonstrated. In addition, a common antiinflammatory effect of tick saliva can contribute to the survival of $B$. burgdorferi at the tick feeding site (Nuttall et al. 2000).
To analyse the SGE effect on regulation of the host immunity, we measured the cytokine production by cells from lymph nodes draining the bacteria inoculation site. Of four chosen cytokines only IFN- $\gamma$ and IL-10 could be detected in unstimulated cell cultures. IFN- $\gamma$ was markedly suppressed on days 5 and 7 p.i. in the SGE-treated group, while the suppression of IL-10 was less pronounced. In ConA-stimulated cultures the relative levels (\% control) of IFN- $\gamma$ exceeded relative levels of IL-10 at all time points observed. The remaining two proinflammatory cytokines were markedly upregulated early post infection and suppressed at later time points.

Infection of mice with $B$. burgdorferi elicits a mixed Th1/Th2 immune response (Christe et al. 2000). The Th2 response is even more pronounced in diseasesusceptible C3H mice (Keane-Myers and Nickell 1995). We also observed a mixed Th1/Th2 cytokine response to $B$. afzelii infection, which was not biased in favour of any $\mathrm{T}$ lymphocyte subset under the influence of tick SGE. The early elevation of IL-6 and GM-CSF cytokine production by lymph node cells from SGE-treated mice in comparison with mice infected without SGE can be caused by an accelerated proliferation of spirochaetes due to an unknown SGE effect. Later the suppressive effect of SGE was similar to that observed by Fuchsberger et al. (1995) and Gwakisa et al. (2001).

Our results are in contrast to those of Zeidner et al. (1997), who demonstrated polarisation to Th2 subset in $\mathrm{C} 3 \mathrm{H} / \mathrm{HeJ}$ mice infected with $B$. burgdorferi via tick feeding. The reason for this discrepancy could be the infectious dose, which was at least 1000 -fold higher in our experiments using syringe inoculation $\left(10^{6}\right.$ spirochaetes/mouse) compared with tick inoculation (estimated dose $10^{2}-10^{3}$ spirochaetes/mouse). Another difference was one-shot inoculation of I. ricinus SGE compared with the long-lasting effect of repeated inoculation of tick saliva during feeding.

Unfortunately, analysis of the cytokine elaboration by cells of lymph nodes draining the site of infection did not elucidate the promotion effect of I. ricinus SGE on B. afzelii infection. After a transient upregulation of both proinflammatory cytokines IL-6 and GM-CSF, these were suppressed by the in vivo effect of SGE. We speculate that a marked $(300 \%)$ increase in IL-6 on day 2 p.i. could induce the development of Th2 lymphocytes (Rincón et al. 1997). However, the anti-inflammatory Th2 cytokine IL-10 was not upregulated and Th1associated IFN- $\gamma$ was markedly suppressed as late as day 7 p.i. It is likely that a direct suppressive effect of SGE on phagocytic cells, histamine-binding and complement-inactivating molecules may contribute to the enhancement of the infectivity of $B$. afzelii spirochaetes at early time points p.i. The real role of these effects in SAT of $B$. afzelii, in addition to the nature of molecules in tick saliva affecting phagocytic cells, remain to be elucidated. 
Acknowledgements. This work was supported by grant No. 524/99/1334 from the Grant Agency of the Czech Republic and grant No. 774/2001 G3 from the Fund for Universities
Development of the Ministry of Education, Youth and Sports of the Czech Republic.

\section{REFERENCES}

CHANG Y.F., NOVOSEL V., CHANG C.F., KIM J.B., SHIN S.J., LEIN D.H. 1998: Detection of human granulocytic ehrlichiosis agent and Borrelia burgdorferi in ticks by polymerase chain reaction. J. Vet. Diagn. Invest. 10: 5659.

CHRISTE M., RUTTI B., BROSSARD M. 2000: Cytokines (IL-4 and IFN- $\gamma$ ) and antibodies (IgE and IgG2a) produced in mice infected with Borrelia burgdorferi sensu stricto via nymphs of Ixodes ricinus ticks or syringe inoculations. Parasitol. Res. 86: 491-496.

EDWARDS J.F., HIGGS S., BEATY B.J. 1998: Mosquito feeding-induced enhancement of Cache Valley virus (Bunyaviridae) infection in mice. J. Med. Entomol. 35: 261-268.

FERREIRA B.R., SILVA J.S. 1999: Successive tick infestations selectively promote a T-helper 2 cytokine profile in mice. Immunology 96: 434-439.

FUCHSBERGER N., KITA M., HAJNICKÁ V., IMANISHI J., LABUDA M., NUTTALL P.A. 1995: Tick salivary gland extracts inhibit expression of lipopolysaccharideinduced mRNA of different human cytokines. Exp. Appl. Acarol. 19: 671-676.

GEORGILIS K., STEERE A.C., KLEMPNER M.S. 1991: Infectivity of Borrelia burgdorferi correlates with resistance to elimination by phagocytic cells. J. Infect. Dis. 163: $150-155$.

GERN L., SCHAIBLE U.E., SIMON M.M. 1993. Mode of inoculation of the Lyme disease agent Borrelia burgdorferi influences infection and immune responses in inbred strains of mice. J. Infect. Dis. 167: 971-975.

GILLESPIE R.D., DOLAN M.C., PIESMAN J., TITUS R.G. 2001: Identification of an IL-2 binding protein in the saliva of the Lyme disease vector tick Ixodes scapularis. J. Immunol. 166: 4319-4327.

GILLESPIE R.D., MBOW M.L., TITUS R.G. 2000: The immunomodulatory factors of bloodfeeding arthropod saliva. Parasite Immunol. 22: 319-331.

GWAKISA P., YOSHIHARA K., TO T.L. GOTOH H., AMANO F., MOMOTANI E. 2001: Salivary gland extract of Rhipicephalus appendiculatus ticks inhibits in vitro transcription and secretion of cytokines and production of nitric oxide by LPS-stimulated JA-4 cells. Vet. Parasitol. 99: 53-61.

HAJNICKÁ V., FUCHSBERGER N., SLOVÁK M., KOCÁKOVÁ P., LABUDA M., NUTTALL P.A. 1998: Tick salivary gland extracts promote virus growth in vitro. Parasitology 116: 533-538.

HAJNICKÁ V., KOCÁKOVÁ P., SLOVÁK M., LABUDA M., FUCHSBERGER N., NUTTALL P.A. 2000: Inhibition of the antiviral action of interferon by tick salivary gland extract. Parasite Immunol. 22: 201-206.

JONES L.D., HODGSON E., NUTTALL P.A. 1989: Enhancement of virus transmission by tick salivary glands. J. Gen. Virol. 70: 1895-1898.
KEANE-MYERS A., NICKELL S.P. 1995: Role of IL-4 and IFN-gamma in modulation of immunity to Borrelia burgdorferi in mice. J. Immunol. 155: 2020-2028.

KUBEŠ M., FUCHSBERGER N., LABUDA M., ŽUFFOVÁ E., NUTTALL P.A. 1994: Salivary gland extracts of partially fed Dermacentor reticulatus ticks decrease natural killer cell activity in vitro. Immunology 82: 113116.

KURTENBACH K., SEWELL H., OGDEN N., RANDOLPH S.E., NUTTALL P.A. 1998: Serum complement sensitivity as a key factor in Lyme disease ecology. Infect. Immun. 66: 1248-1251.

KUTHEJLOVÁ M., KOPECKÝ J., ŠTĚPÁNOVÁ G., MACELA A. 2001: Tick salivary gland extract inhibits killing of Borrelia afzelii spirochetes by mouse macrophages. Infect. Immun. 69: 575-578.

LABUDA M., NUTTALL P.A., KOŽUCH O., ELEČKOVÁ E., WILLIAMS T., ŽUFFOVÁ E., SABÓ A. 1993: Nonviremic transmission of tick-borne encephalitis virus. A mechanism for arbovirus survival in nature. Experientia 49: 802-805.

MAGNUSSON H.J., HILL C., FLEISCHMAN R. 1948: The minimal infectious inoculum of Spirochaeta pallida (Nichols strain) and a consideration of its rate of multiplication in vivo. Am. J. Syph. Gonorrh. Ven. Dis. 32: 1-18.

MBOW M.L., BLEYENBERG J.A., HALL L.R., TITUS R.G. 1998: Phlebotomus papatasi sand fly salivary gland lysate down-regulates a Th1, but up-regulates a Th2, response in mice infected with Leishmania major. J. Immunol. 161: 5571-5577.

NUTTALL P.A. 1999: Pathogen-tick-host interactions: Borrelia burgdorferi and TBE virus. Zentralbl. Bakteriol. 289: 492-505.

NUTTALL P.A., JONES L.D. 1991: Non-viraemic tick-borne virus transmission: mechanisms and significance. In: F. Dusbábek and V. Bukva (Eds.), Modern Acarology, Vol. 2. Academia Prague and SPB Academic Publishing bv, the Hague, pp. 3-6.

NUTTALL P.A., PAESEN G.C., LAWRIE C.H., WANG H. 2000: Vector-host interactions in disease transmission. J. Mol. Microbiol. Biotechnol. 2: 381-386.

OGDEN N.H., NUTTALL P.A., RANDOLPH S.E. 1997: Natural Lyme disease cycles maintained via sheep by cofeeding ticks. Parasitology 115: 591-599.

PAESEN G.C., ADAMS P.L., HARLOS K., NUTTALL P.A., STUART D.I. 1999: Tick histamine-binding proteins: isolation, cloning and three-dimensional structure. Mol. Cell 3: 661-671.

RIBEIRO J.M.C. 1987: Ixodes dammini: salivary anticomplement activity. Exp. Parasitol. 64: 347-353.

RIBEIRO J.M.C., SPIELMAN A. 1986: Ixodes dammini: salivary anaphylatoxin inactivating activity. Exp. Parasitol. 62: 292-297. 
RIBEIRO J.M.C., WEISS J.J., TELFORD III S.R. 1990: Saliva of the tick Ixodes dammini inhibits neutrophil function. Exp. Parasitol. 70: 382-388.

RINCÓN M., ANGUITA J., NAKAMURA T., FIKRIG E., FLAVELL R.A. 1997: Interleukin (IL)-6 directs the differentiation of IL-4-producing $\mathrm{CD}^{+} \mathrm{T}$ cells. J. Exp. Med. 185: 461-469.

SCHOELER G.B., MANWEILER S.A., WIKEL S.K. 1999: Ixodes scapularis: effect of repeated infestations with pathogen-free nymphs on macrophage and $\mathrm{T}$ lymphocyte cytokine response of $\mathrm{BALB} / \mathrm{c}$ and $\mathrm{C} 3 \mathrm{H} / \mathrm{HeN}$ mice. Exp. Parasitol. 92: 239-248.

ŠTĚPÁNOVÁ-TRESOVÁ G., KOPECKÝ J., KUTHEJLOVÁ M. 1999: Identification of Borrelia burgdorferi sensu stricto, Borrelia garinii and Borrelia afzelii in Ixodes ricinus ticks from Southern Bohemia using monoclonal antibodies. Zentralbl. Bakteriol. 289: 797-806.

THEODOS C.M., RIBEIRO J.M.C., TITUS R.G. 1991: Analysis of enhancing effect of sand fly saliva on
Leishmania infection in mice. Infect. Immun. 59: 15921598.

URIOSTE S., HALL L.E., TELFORD III S.R., TITUS R. 1994: Saliva of the Lyme disease vector, Ixodes dammini, blocks cell activation by a nonprostaglandin E2-dependent mechanism. J. Exp. Med. 180: 1077-1085.

WANG H., NUTTALL P.A. 1995: Immunoglobulin-G binding proteins in the ixodid ticks, Rhipicephalus appendiculatus, Amblyomma variegatum and Ixodes hexagonus. Parasitology 111: 161-165.

WIKEL S.K. 1982: Influence of Dermacentor andersoni infestation on lymphocyte responsiveness to mitogens. Ann. Trop. Med. Parasitol. 76: 627-632.

ZEIDNER N., MBOW M.L., DOLAN M., MASSUNG R., BACA E., PIESMAN J. 1997: Effects of Ixodes scapularis and Borrelia burgdorferi on modulation of the host immune response: induction of a $\mathrm{TH} 2$ cytokine response in Lyme disease-susceptible $(\mathrm{C} 3 \mathrm{H} / \mathrm{HeJ})$ mice but not in disease-resistant $(\mathrm{BALB} / \mathrm{c})$ mice. Infect. Immun. 65: 3100-3106.

Accepted 15 November 2001 